\title{
Hemoglobinopathy and Systemic Lupus: A Rare Association
}

\author{
Assétou Kaya Soukho*, Ibrahima Amadou Dembele, Aldiouma Guindo, Djenebou Traore, \\ Nounga Romuald Nyanke, Djibril Sy, Abasse Sanogo, Mamadou Cissoko, \\ Barry Boubacar Sangare, Mamadou Malle, Sékou Mamadou Cisse, Abdramane Traore, \\ Mahamadou Saliou, Nanko Doumbia, Brehima Boly Berthe, Kaly Keita, Boubacar Zoumana Cisse, \\ Drissa Sangare, Youssouf Fofana, Kokou Tbah Tighankpa, Adramé Keita, Mamadou Keita, \\ Mamadou Dembele, Abdel Kader Traore, Hamar Alassane Traore
}

Department of Internal Medicine, Point G University Teaching Hospital, Bamako, Mali

Email:*assetousouko@yahoo.fr

How to cite this paper: Soukho, A.K., Dembele, I.A., Guindo, A., Traore, D., Nyanke, N.R., Sy, D., Sanogo, A., Cissoko, M., Sangare, B.B., Malle, M., Cisse, S.M., Traore, A., Saliou, M., Doumbia, N., Berthe, B.B., Keita, K., Cisse, B.Z., Sangare, D., Fofana, Y., Tighankpa, K.T., Keita, A., Keita, M., Dembele, M., Traore, A.K. and Traore, H.A. (2019) Hemoglobinopathy and Systemic Lupus: A Rare Association. Open Journal of Internal Medicine, 9, 72-77. https://doi.org/10.4236/ojim.2019.93010

Received: June 27, 2019

Accepted: August 31, 2019

Published: September 3, 2019

Copyright $\odot 2019$ by author(s) and Scientific Research Publishing Inc. This work is licensed under the Creative Commons Attribution International License (CC BY 4.0). http://creativecommons.org/licenses/by/4.0/

\begin{abstract}
The authors report a case of systemic lupus associated with a composite heterozygosis SC with thalassemic component in a 19-year-old patient hospitalized for anemia and polyarthralgia who has a staturoponderal delay, macular erythematous lesions in butterfly wings on the face and ears, photosensitivity, puffy face, alopecia, pubic and axillary hair loss, scalp dermatophytosis, painful swelling of the interphalangeal joints, wrists and knees. The hemoglobin electrophoresis showed a compound heterozygote SC associated with $\beta$ thalassemia. Antinuclear antibodies were positive with an anti-Sm positive antibody. Conclusion: The diagnosis of both diseases can be difficult when symptoms are concomitant and look alike.
\end{abstract}

\section{Keywords}

Hemoglobinopathy, Lupus, University Teaching Hospital Point G

\section{Introduction}

Sickle cell disease is an autosomal recessive genetic disorder characterized by the presence of abnormal S-hemoglobin responsible for more or less important vaso-occlusive manifestations. This hemoglobin $S$ is the consequence of a punctual mutation resulting in the replacement in the globin chain of glutamic acid by valine [1]. Its highest frequencies are in sub-Saharan Africa. In Mali, sickle cell disease is a major public health problem with an average frequency of $12 \%$ of the $\mathrm{Hb}$ S allele according to a North-South gradient [2]. Since 2005, 5000 to 6000 
sickle cell births have been recorded in Mali [3] [4].

Systemic lupus is an autoimmune disease characterized by a dysfunction of the immune system. This rare condition affects more often young women.

Lupus, as well as sickle cell disease, is a hemolytic disease. However, their coexistence in the same individual is rarely described.

This report describes a case of association of sickle cell disease and systemic lupus in a young woman, admitted to the Internal Medicine department of the University Teaching Hospital of point G.

\section{Observation}

Miss R B aged 19 hospitalized at the internal medicine department of University Teaching Hospital of point $\mathrm{G}$ for anemic syndrome associated with polyarthralgia and warm joint swelling interesting the two handles, both elbows, both knees, metacarpophalangeal and proximal interphalangeal joints making movement difficult without morning stiffness; erythematous-macular cutaneo-mucosal lesions on the face shown in Figure 1, ears and the rest of the body aggravated by exposure to the sun in a context of ongoing unquantified weight loss since 2 years.

On physical examination, the patient showed a staturoponderal delay, a conjunctival pallor, erythemato-macular lesions in butterfly wings localized on the face and ears, a photosensitivity, puffy face, alopecia shown in Figure 2, fall the pubic and axillary hair, scalp dermatophytosis, painful swelling of the interphalangeal joints, wrists, and knees and splenomegaly of $10 \mathrm{~cm}$ from the left costal margin with lymphadenopathy about 3 centimeters, consistency firm, painless, mobile, left sub-mandibular, bilateral supraclavicular, bilateral axillary and bilateral inguinal.

The hemogram noted an anemia at $6.1 \mathrm{~g} / \mathrm{dl}$, normocytic (MGV $=87 \mathrm{fl})$, normochromic, non-regenerative (Reticulocytes $=34,000 / \mathrm{mm}^{3}$ ). It was a hemolytic anemia because of the haptoglobin rate at $0.06 \mathrm{~g} / \mathrm{L}(\mathrm{N}=0.35-2.5 \mathrm{~g} / \mathrm{l})$ the lactodeshydrogenase level at $1026 \mathrm{IU} / \mathrm{l}(\mathrm{N}=200-600 \mathrm{IU} / \mathrm{l})$ and an indirect hyperbilirubinemia at $0.22 \mathrm{mg} / \mathrm{dl}$ with the positive IgG at direct Coombs test.

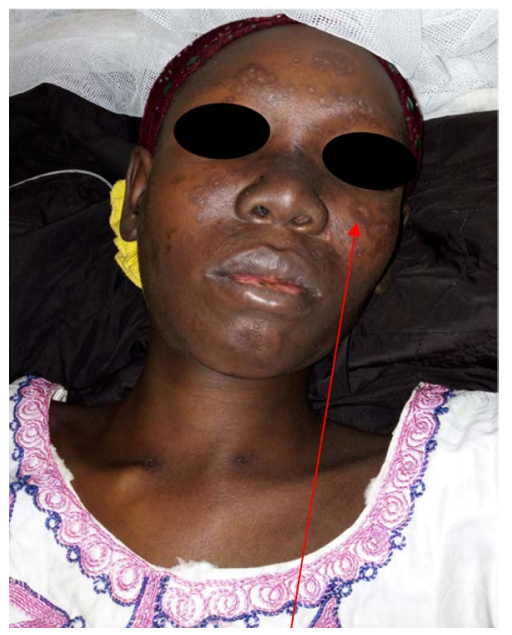

Figure 1. Malar erythema. 
The hemoglobin electrophoresis showed an $\mathrm{Hb} \mathrm{S}$ at $47.1 \%, \mathrm{Hb} \mathrm{C}$ at $42.1 \%, \mathrm{Hb}$ $\mathrm{F}$ at $6.5 \%$ and $\mathrm{Hb} \mathrm{A} 2$ at $4.3 \%$. (Composite heterozygous SC associated with $\beta$-thalassemia).

Serology (HIV serology, hepatitis B and C viral serology) were negative.

Chest radiography was normal. Wrists, elbows, and knees X-rays showed bone demineralization that can be seen in Figure 3.

Abdominopelvic ultrasound, apart from splenomegaly, was normal.

C3 (0.45 g/l, N: $0.82-1.93)$ and C4 (0.06 g/l, N: 0.10 - 0.40) fractions of sera complement were low and proteinuria was absent. Antinuclear antibodies (10.82 $\mathrm{IU} / \mathrm{ml}, \mathrm{N}<1)$ ) were positive with anti Sm antibody (20 IU, $\mathrm{N}<10$ ).

The diagnosis of systemic lupus associated with SC composite heterozygosis

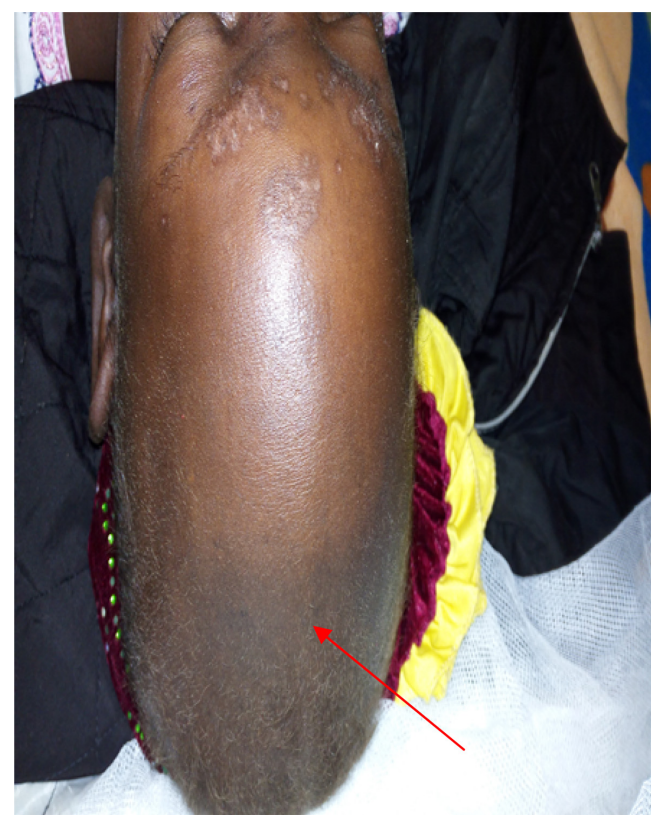

Figure 2. Alopecia.

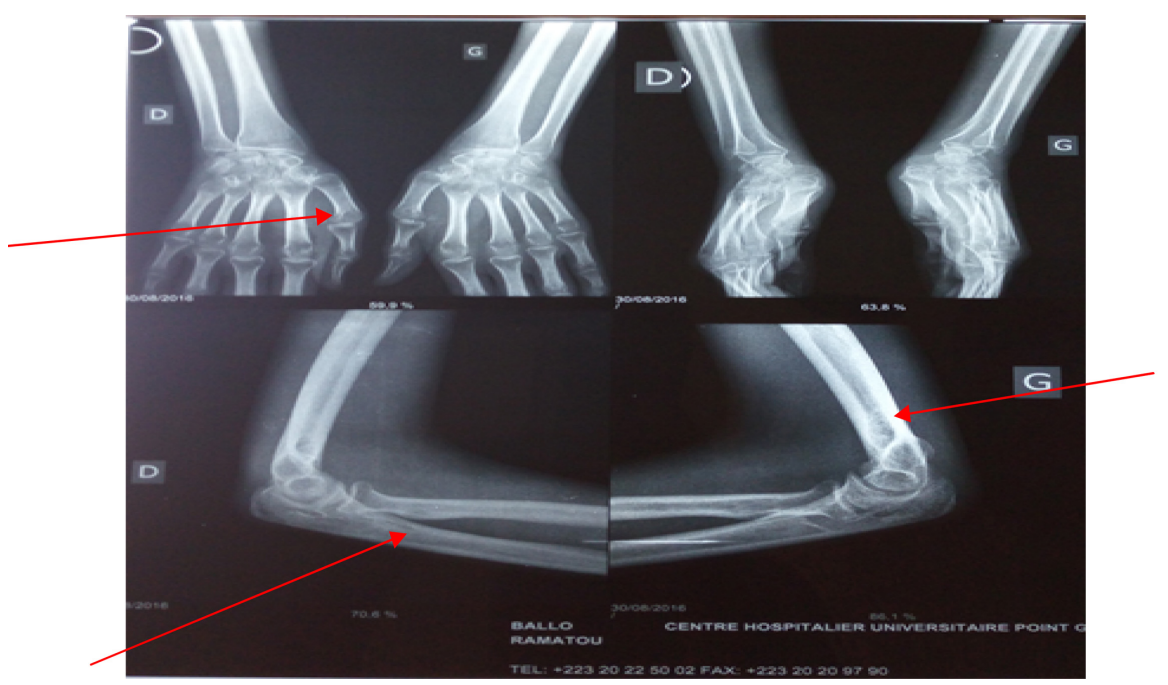

Figure 3. Bone radiograph of wrists and elbows: shows bone demineralization. 
with thalassemic component was finally retained.

Corticosteroid therapy was initiated for the patient based on oral (prednisone) at a dose of $30 \mathrm{mg} /$ day, which was reduced to $5 \mathrm{mg}$ /day with adjuvant therapy and on antimalarial synthesis drug (hydroxychloroquine) with two tablets of 200 mg per day.

The evolution was favorable with the decrease of painful crisis and lupus symptomatology (general signs, joint symptoms, and the tumor syndrome).

\section{Discussion}

Mali is located in West Africa, in the area of distribution of hemoglobin S. A center for research and fights against sickle cell disease was created in Bamako; this allowed the diagnosis of a large number of hemoglobinopathy with even early diagnosis.

Few studies show the association between rheumatological pathology with hemoglobinopathies.

Robazzi et al. [5] in 2012, counted 45 cases of association between sickle cell disease to lupus. Other studies [6] [7] [8] [9] [10] also showed this association in the literature with 56 cases as of July 2017. Despite this association, it is rarely reported. These pathologies have in common clinical symptoms except cutaneous lesions not described in sickle cell disease and ulcer of limps not described in lupus. The prevalence of this association is not known because most of them are reported cases.

Pathogenically, the lack of activation of the alternative complement pathway observed during sickle cell disease leads to a reduction in the elimination of antigens responsible for the formation of immune complexes that may be responsible for the emergence of autoimmune diseases [11] [12], although data are missing to confirm this hypothesis.

Three studies have described the production of antinuclear antibodies (ANA) between $17.3 \%$ and $48.9 \%$ [13] [14] [15] in patients with sickle cell disease than the rest of the population. They also suggested the role of certain factors such as genetics or environmental causes that may favor the production of these antibodies. Very few studies have investigated the occurrence of autoimmune diseases, especially lupus in this field [16] [17] [18] [19]. Thus, the prevalence of native anti-DNA antibodies is poorly known because most studies are reported cases. Therefore, other studies are still to be done.

We have described the case of a patient for whom the diagnosis of hemoglobinopathy and lupus with high activity index (SLEDAI $=20$ ) simultaneously. What would have helped with this is already the epidemiology of the two diseases, which tends to be superimposed particularly in our skies at this age, but also the clinical similarity of the two affections. Cutaneous lesions were directing to lupus while the hand-foot syndrome history in childhood to sickle cell disease.

The late discovery of sickle cell disease could be explained by the low level of education of the population but also the social level. 


\section{Conclusion}

The diagnosis of both diseases can be difficult when the symptoms are concomitant and similar. Osteoarticular pain is a very common sign in these two conditions.

\section{Conflicts of Interest}

The authors declare no conflicts of interest regarding the publication of this paper.

\section{References}

[1] Piel, F.B., Steinberg, M.H. and Rees, D.C. (2017) Sickle Cell Disease. The New England Journal of Medicine, 376, 561-573. https://doi.org/10.1056/NEJMra1510865

[2] Diallo, D. and Guindo, A. (2014) Sickle Cell Disease in Sub-Saharan Africa: Stakes and Strategies for Control of Disease. Current Opinion in Hematology, 21, 210-214. https://doi.org/10.1097/MOH.0000000000000038

[3] Diallo, D. (2008) Cell Sickle Disease in Africa: Current Situation and Strategies for Improving the Quality and Duration of Survival. Bulletin de L'Académie Nationale de Médecine, 192, 1361-1372.

[4] ENMP (1981) Health Assessment of Kéniéba, Bafoulabé, Kita circles (Kayes Region, Republic of Mali). PDS, World Bank, Final Report.

[5] Robazzi, T.C.M.V., Alves, C., Abreu, L. and Lemos, G. (2015) Coexistência de lúpus eritematoso sistêmico e doenca falciforme: Relato de caso and revisão da literature. Revista Brasileira de Reumatologia, 55, 68-74. https://doi.org/10.1016/j.rbr.2013.05.005

[6] Idris, A.B., Abdulgayoom, A., Mudawi, E., El Hassan, A.M., Elamin, E.M. and El Hassan, L.A.M. (2015) Coexistence of Sickle Cell Nephropathy and Lupus Nephritis in Sudanese Child. Saudi Journal of Kidney Disease and Transplantation, 26 584-588. https://doi.org/10.4103/1319-2442.157397

[7] Minocha, V. and Rana, F. (2013) Lupus Nephritis in Patients with Sickle Cell Disease. Case Reports in Hematology, 2013, Article ID: 907950.

https://doi.org/10.1155/2013/907950

[8] Maamar, Mr., Tazi Mezalek, Z., Moumfaloti, W., Harmouche, H., Adnaoui, Mr. and Aouni, Mr. (2012) Sickle Cell Disease and Systemic Lupus: A Rare Association. Review of the Medical, 3, 342.

[9] Lee, A.C.-W. and Al-Saad, K.K. (2013) Successful Hematopoietic Cell Transplantation in a Child with Sickle Cell Disease and Systemic Lupus Erythematosus. Bone Marrow Transplantation, 48, 151-152. https://doi.org/10.1038/bmt.2012.106

[10] Cherner, M. and Isenberg, D. (2010) The Overlap of Systemic Lupus Erythematosus and Sickle Cell Disease: Report of Two Cases and a Review of the Literature. Lupus, 19, 875-883. https://doi.org/10.1177/0961203309356291

[11] Galmiche, S., et al. (2016) Autoimmune Diseases in Major Sickle Cell Syndromes: A Study of 26 Cases. The Journal of Internal Medicine, 37S, A27-A88.

[12] Wilson, W.A., Deceulaer, K. and Morgan, A.G. (1979) Sickle Cell Anemia, Complement, and Systemic Lupus Erythematosus. Rheumatoid Arthritis, 22, 803. https://doi.org/10.1002/art.1780220721

[13] Koethe, S.M., Casper, J.T. and Rodey, G.E. (1976) Alternative Pathway Activity Will 
Be from Patients with Sickle Cell Disease. Clinical \& Experimental Immunology, 23, 56-60.

[14] Toly-Ndour, C., Rouquette, A.M., Obadia, S., M’bappe, P., Lionel, F., Hagege, I., Boussa Khetab, F., Tshilolo, L. and Girrot, R. (2011) High Titers of Autoantibodies in Patients with Sickle Cell Disease. The Journal of Rheumatology, 38, 302-309. https://doi.org/10.3899/jrheum.100667

[15] Baethge, B.A., Bordelon, T.R., Mills, G.M., Bowen, L.M., Wolf, R.E. and Bairnsfather, L. (1990) Antinuclear Antibodies in Sickle Cell Disease. Acta Haematologica, 84, 186-189. https://doi.org/10.1159/000205060

[16] Abbas, M., Bolad, A., Rida, M., Jiefri, N. and Mergani, A. (2013) Prevalence of Anti-Double Stranded DNA among Homozygous Sickle Cell Disease in Sudan. Clinical Medicine and Diagnostics, 3, 75-81.

[17] Michel, M., Habibi, A., Godeau, B., Bachir, D., Lahari, A., Galacteros, F., et al. (2008) Characteristics and Outcome of Connective Tissue Diseases in Patients with Sickle Cell Disease: Report of 30 Cases. Seminars in Arthritis and Rheumatism, 38, 228-240. https://doi.org/10.1016/j.semarthrit.2007.10.003

[18] Michel, Mr., Fifi, A., Bachir, D., Schaeffer, A., Godeau, B., Galacteros, F. and Arfi, S. (2000) Sickle Cell Disease and Connective Tissue Diseases: A Retrospective Study of 16 Patients. La Revue de Médecine Interne, 21, 530. https://doi.org/10.1016/S0248-8663(00)90079-1

[19] Ouedraogo, D.-D., Nacoulma, E.W.C., Kafando, E., Ouedraogo, A., Tieno, H., Koulidiaty, J. and Drabo, J.Y. (2010) Rheumatologic Pathologies and Hemoglobinopathies in Ouagadougou (Burkina Faso). Bulletin de la Société de Pathologie Exotique, $103,80-83$. 